\title{
Seryl-tRNA synthetase-mediated essential amino acids regulate $\beta$-casein synthesis via cell proliferation and mammalian target of rapamycin (mTOR) signaling pathway in bovine mammary epithelial cells
}

\author{
W. T. Dai, ${ }^{*}$ R. R. White, $†$ J. X. Liu, ${ }^{*}$ and H. Y. Liu† ${ }^{1}$ \\ ${ }^{*}$ College of Animal Sciences, Zhejiang University, Hangzhou 310058, China \\ †Department of Animal and Poultry Science, Virginia Tech, Blacksburg 24060
}

\begin{abstract}
Essential amino acids (EAA) play an important role in promoting milk protein synthesis in primary bovine mammary epithelial cells (BMEC). However, the regulatory mechanisms involved in the relationship between EAA and milk protein synthesis have not been fully explored. This study examined the effects of seryl-tRNA synthetase (SARS) on EAA-stimulated $\beta$-casein synthesis, cell proliferation, and the mammalian target of rapamycin (mTOR) system in BMEC. First, BMEC were cultured in medium either lacking all EAA (-EAA) or that included all EAA (+EAA) for $12 \mathrm{~h}$. The BMEC were then supplemented with the opposing treatments ( - EAA supplemented with + EAA and vice versa) for $0 \mathrm{~h}, 10 \mathrm{~min}, 0.5 \mathrm{~h}, 1 \mathrm{~h}, 6 \mathrm{~h}$, or $12 \mathrm{~h}$, respectively. After the treatment-specific time allotment, proteins were collected for Western blotting. Subsequently, a $2 \times 2$ factorial design was used to evaluate the interactive of SARS inhibition (control or SARS inhibited) and EAA supply (+EAA or -EAA) on gene and protein abundance, cell viability, and cell cycle in BMEC. Based on the data obtained in the first experiment, the changes in protein abundance of $\beta$-casein and SARS depended on EAA treatment time in similar patterns. The protein abundance of $\beta$-casein, SARS, and mammalian target of rapamycin (mTOR)-related proteins, cell viability, cell cycle progression, and the mRNA abundance of cyclin D1 (CCND1, cell cycle progression marker) and marker of proliferation Ki-67 (MKI67, cell proliferation marker) were stimulated by the presence of EAA. Correspondingly, when cells were deprived of EAA, cell proliferation and abundance of these proteins and genes were reduced overall. Moreover, the decreases in
\end{abstract}

Received February 10, 2018.

Accepted July 25, 2018.

${ }^{1}$ Corresponding author: hyliu@zju.edu.cn these aspects were further exacerbated by inhibiting SARS, suggesting that an interaction between EAA and SARS is important for regulating protein synthesis. The results indicated that SARS stimulated the mTOR signaling pathway when EAA were present, enhanced EAA-stimulated cell proliferation, and contributed to increased $\beta$-casein production in BMEC.

Key words: bovine mammary epithelial cells, essential amino acids, $\beta$-casein synthesis, cell proliferation, mammalian target of rapamycin (mTOR)

\section{INTRODUCTION}

Milk proteins produced by the mammary gland of dairy cows are one of the highest quality protein sources available for human consumption. Several factors, including hormones (e.g., prolactin and insulin; Bequette et al., 2001; Burgos et al., 2010), nutrients (e.g., amino acids and glucose; Appuhamy et al., 2011, 2014), and environmental stressors (e.g., heat stress and cold stress; Collier et al., 2006; Hu et al., 2016) are known to affect milk protein synthesis. Of those dietary nutrients understood to influence milk protein synthesis, the EAA are among the most important because they provide the substrates for protein synthesis and act as regulators of casein synthesis in the bovine mammary gland tissues (Appuhamy et al., 2011; Li et al., 2017). Importantly, several studies have demonstrated that EAA stimulate cell proliferation of bovine mammary epithelial cells (BMEC; Theodorou et al., 2011; Luo et al., 2018). By measuring mammary epithelial cell DNA, Capuco et al. (2001) found that during lactation, the number of mammary epithelial cells within the mammary glands gradually decreases, largely accounting for the decline in milk production with advancing lactation. Therefore, it appears that EAA-stimulated expansion of epithelial cell populations in the mammary gland especially during lactation may further promote milk yield (Ellis and Capuco, 2002; Arendt and Kuperwasser, 2015). An additional regulator of milk protein syn- 
thesis is the mammalian target of rapamycin (mTOR) signaling pathway, one of the main mechanisms by which EAA regulate casein synthesis (Appuhamy et al., 2011; Guo et al., 2017; Li et al., 2017). Once activated, mammalian target of rapamycin complex 1 (mTORC1) is phosphorylated and subsequently stimulates the downstream proteins - ribosomal protein $\mathrm{S} 6$ kinase 1 (S6K1) and eukaryotic initiation factor (eIF) $4 \mathrm{E}$ binding protein 1 (4EBP1) - which promote the release of $4 \mathrm{EBP} 1$ from the key initiation factor (eIF4E) and strengthen the translation initiation process (Appuhamy et al., 2011; Shimobayashi and Hall, 2014). Although the relationships between mTORC1 and its downstream factors (S6K1 and 4EBP1) are well characterized, other aspects of this pathway remain unclear in ruminants. Thus, there is an urgent need to expand research on AA signaling within the mTOR pathway and to further elucidate the underlying mechanisms by which AA influences milk protein production.

In the past decade, several studies have explored the potential functional roles of aminoacyl-tRNA synthetase (AARS) in the regulation of cellular metabolism (Kyriacou and Deutscher, 2008; Yao and Fox, 2013; Pang et al., 2014). For example, Park et al. (2008) first demonstrated that AARS were essential for protein synthesis and cell viability in eukaryotic organisms. Subsequently, Han et al. (2012) identified that leucyl-tRNA synthetase (LARS) was an intracellular AA sensor for mTORC1 signaling in human $293 \mathrm{~T}$ cells. Corresponding roles of AARS in BMEC were subsequently identified (Wang et al., 2014). Additionally, transcriptomic and proteomic studies have demonstrated that seryltRNA synthetase (SARS) was the most abundantly and significantly expressed gene at both the mRNA and protein levels when comparing mammary gland tissues from dairy cows fed varying roughages (corn stover vs. alfalfa hay) or dairy cows during different stages of lactation (dry period vs. mid lactation; Dai et al., 2017a,b, 2018). Collectively, the previous studies suggest that SARS may play a vital role in milk protein synthesis. In this study, we aimed to investigate the role of SARS in response to EAA during the process of $\beta$-casein synthesis in BMEC.

\section{MATERIALS AND METHODS}

\section{Ethics Statement}

Experimental protocols were approved by the Animal Care Committee, Zhejiang University (Hangzhou, P. R. China), and the care and handling of the dairy cows from the mammary tissues obtained were in compliance with the Guidelines of China for Animal Care.

\section{Cells and Tissue Culture}

Primary BMEC were isolated and cultured as described previously (Zhao et al., 2010; Supplemental Figure S1; https://doi.org/10.3168/jds.2018-14568). Unless otherwise stated, the cells were seeded in 10$\mathrm{cm}^{2}$ plates and cultured in Dulbecco's modified Eagle medium (DMEM)-F12 medium (12500062, Gibco/ ThermoFisher Scientific, Waltham, MA), supplemented with 10\% fetal bovine serum (FBS, 10099141, Gibco/ ThermoFisher Scientific), 1\% L-glutamine (G8540, Sigma, St. Louis, MO), $5 \mu \mathrm{g} / \mathrm{mL}$ transferrin (T1283, Sigma), $5 \mu \mathrm{g} / \mathrm{mL}$ insulin (I5500, Sigma), $5 \mu \mathrm{g} / \mathrm{mL}$ prolactin (L6520, Sigma), 1 g/mL hydrocortisone (H0888, Sigma), $10 \mathrm{ng} / \mathrm{mL}$ epidermal growth factor (E4127, Sigma), and $1 \%$ penicillin-streptomycin (C0222, Beyotime, Jiangsu, China). Plates were incubated at $37^{\circ} \mathrm{C}$ in a humidified atmosphere containing $5 \% \mathrm{CO}_{2}$.

\section{RNA Interference}

For SARS [National Center for Biotechnology Information NCBI accession no. NM_174175.3] and methionyl-tRNA synthetase ( $\boldsymbol{M A R} \boldsymbol{R}$; NCBI accession no. NM_001038091.2) mRNA interference, cells cultured in 6-well plates were transfected with $80 \mathrm{n} M$ small interfering RNA (siRNA) using a transfection reagent (Lipofectamine RNAiMAX transfection reagent; Invitrogen, Carlsbad, CA) in lactogenic medium without antibiotic according to the manufacturer's instructions. After $24 \mathrm{~h}$ of the initial transfection of si-SARS and si-MARS, BMEC were treated with EAA medium 6 $\mathrm{h}$ later for RNA extraction and protein collection, 24 $\mathrm{h}$ later for cell viability and cell cycle assays, and 2 $\mathrm{d}$ later for the protein turnover assay. Four sequences of the siRNA oligonucleotides for SARS and one for MARS were designed and synthesized by GenePharma Biotechnology Co. Ltd. (Shanghai, China) as described in Supplemental Table S1 (https://doi.org/10.3168/jds .2018-14568). Scrambled siRNA is a functional nontargeting siRNA that was used as a negative control (si-NC).

\section{Treatments and Experimental Design}

To measure the effects of the treatment duration of EAA deprivation (DMEM-F12 devoid of all EAA, -EAA) and EAA supplement (complete DMEM-F12, +EAA) on the relative protein abundance of SARS and $\beta$-casein, BMEC cultured in 6-well plates were first serum-starved overnight and subsequently treated with EAA deprivation (-EAA) followed by EAA resupplement (+EAA) for $10 \mathrm{~min}, 0.5 \mathrm{~h}, 1 \mathrm{~h}, 6 \mathrm{~h}$, and $12 \mathrm{~h}$. 
In a different set of plates, the treatment order (EAA supplement followed by EAA deprivation) was reversed. After treatments, BMEC were immediately collected and lysed at the respective treatment time points by using $0.25 \mathrm{~mL}$ of lysis buffer for $1 \mathrm{~h}$ on ice, as described in Wu et al. (2012). The homogenates were centrifuged at $12,000 \times g$ for $5 \mathrm{~min}$ at $4^{\circ} \mathrm{C}$, and the supernatants were collected as protein samples for the Western blot assay. All media were prepared as lactogenic media as described above, and all treatments were represented in triplicate and the experiment was repeated 3 times on 3 different days.

Subsequently, a $2 \times 2$ factorial design was used to evaluate the interacting effects of SARS inhibition (wild-type, WT, or SARS knockdown, si-SARS) and EAA supply (+EAA or -EAA) on casein expression, protein turnover, cell viability, cell cycle, and the mTOR system, yielding 4 treatments: -EAA/WT, + EAA/WT, -EAA/si-SARS, and +EAA/si-SARS. At approximately 80 to $90 \%$ confluence, these cell types were serum-starved overnight and treated with medium devoid (-EAA) or replete $(+\mathrm{EAA})$ with EAA for 6 $\mathrm{h}$ to collect RNA and protein, for $24 \mathrm{~h}$ to determine cell viability and cell cycle, and for $2 \mathrm{~d}$ to measure total protein synthesis and protein degradation. All treatment media were prepared as lactogenic media as described above, and all treatments were represented in triplicate and the experiment was repeated 3 times on 3 different days.

\section{Total RNA Extraction and Quantitative Real-Time PCR}

Total RNA was extracted from mammary cells with Trizol reagent (Invitrogen) and purified with Qiagen RNeasy kit (Qiagen, Valencia, CA). The quantified RNA was reverse transcribed for cDNA synthesis using a PrimeScriptRT Reagent Kit with gDNA Eraser (Takara, Tokyo, Japan) following the manufacturer's instructions. The quantitative real-time PCR was performed in triplicate using Applied Biosystems 7500 real-time PCR system (Applied Biosystems, Foster City, CA). The $20-\mu \mathrm{L}$ reaction included $50 \mathrm{ng}$ of reverse transcription product, $40 \mathrm{n} M$ each forward and reverse primer [Supplemental Table S2, https://doi.org/10 .3168/jds.2018-14568; designed by Primer 5 software (Premier Biosoft International, Palo Alto, CA)], and the SYBR Premix Taq (Takara). The running program was 1 cycle of $95^{\circ} \mathrm{C}$ for $30 \mathrm{~s}$ plus 40 cycles of amplification at $95^{\circ} \mathrm{C}$ for $5 \mathrm{~s}$ and $58^{\circ} \mathrm{C}$ for $34 \mathrm{~s}$, followed by an additional $15 \mathrm{~s}$ at $95^{\circ} \mathrm{C}, 1 \mathrm{~min}$ at $60^{\circ} \mathrm{C}$, and $15 \mathrm{~s}$ at $95^{\circ} \mathrm{C}$ to generate the melt curve. The relative gene expression values were calculated by the $2^{-\Delta \Delta \mathrm{Ct}}$ method (Livak and Schmittgen, 2001). The relative mRNA abundance of target genes was normalized to those of keratin 8 (KRT8) and ribosome protein 9 (RPS9).

\section{Western Blotting}

Protein lysates were centrifuged at $12,000 \times g$ for $5 \mathrm{~min}$ and the supernatants were collected and measured for the protein concentration using the bicinchoninic acid (BCA) protein assay kit (Beyotime, Jiangsu, China). Protein levels were analyzed by Western blotting according to previously described procedures (Dai et al., 2017a). Approximately $40 \mu \mathrm{g}$ of protein per sample was separated on $12 \%$ SDS polyacrylamide gels. Proteins were transferred onto $0.45-\mu \mathrm{m}$ polyvinyldifluoride (PVDF) membranes (IPVH00010; Millipore, Billerica, MA) and blocked with blocking buffer (P0023B, Beyotime). The membranes were incubated with primary antibodies to mouse anti- $\beta$-casein (working concentration $5 \mu \mathrm{g} / \mathrm{mL}$, dilution 1:500; orb18512, Biorbyt, Cambridge, UK), mouse anti- $\beta$-actin $(5 \mu \mathrm{g} /$ $\mathrm{mL}, 1: 1,000$; AF0003, Beyotime), rabbit anti-mTOR $(2.5 \mu \mathrm{g} / \mathrm{mL}, 1: 1,000 ; 2933$,Cell Signaling Technology, Danvers, MA), rabbit anti-p-mTOR (Ser2448, $2.5 \mu \mathrm{g} /$ mL, 1:1,000; ab84400, Abcam, Cambridge, MA), rabbit anti-S6K1 $(2.5 \mu \mathrm{g} / \mathrm{mL}, 1: 1,000$; ab9366, Abcam), rabbit anti-p-S6K1 (Thr389; $2.5 \mu \mathrm{g} / \mathrm{mL}, 1: 1,000 ; 9205$, Cell Signaling Technology), rabbit anti-4EBP1 (2 $\mu \mathrm{g} /$ mL, 1:1,000; 4923, Cell Signaling Technology), rabbit anti-p-4EBP1 (Thr37/46; $2 \mu \mathrm{g} / \mathrm{mL}, 1: 1,000 ; 2855$, Cell Signaling Technology) and rabbit anti-SARS $(2.5 \mu \mathrm{g} /$ $\mathrm{mL}$, 1:1,000; ab154825, Abcam) in blocking buffer, respectively. After washing 3 times with Tris-buffered saline containing $0.02 \%$ (vol/vol) Tween-20, the membranes were incubated with goat anti-rabbit IgG (5 $\mu \mathrm{g} / \mathrm{mL}, 1: 500$; A0208, Beyotime) or goat anti-mouse IgG secondary $(2.5 \mu \mathrm{g} / \mathrm{mL}, 1: 500$; A0216, Beyotime) antibodies conjugated with horseradish peroxidase, incubated with electrochemiluminescence (ECL) Western Blotting Substrate Kits (P0018, Beyotime), and finally visualized using a chemiluminescence system (CLiNX Science Instrument, Shanghai, China). The relative intensities of bands were calculated with ImagePro Plus 6.0 software (Media Cybernetics, Rockville, MD) using $\beta$-actin as the reference protein. The intensities of protein bands were analyzed with ImageJ2X software (version 1.32; National Institutes of Health, Bethesda, $\mathrm{MD})$ and normalized against corresponding bands of $\beta$-actin in the same sample.

\section{Protein Turnover Assays}

Protein turnover was determined by using a stable isotope labeling method. To measure protein synthesis, BMEC were cultured in -EAA/+EAA DMEM 
containing 5\% FBS for $2 \mathrm{~d}$. The cells were washed 3 times with $2 \mathrm{~mL}$ of DMEM (-EAA) and cultured for $3 \mathrm{~h}$ in $2 \mathrm{~mL}$ of $-\mathrm{EAA} /+\mathrm{EAA}$ DMEM containing $5 \%$ FBS, $1 \mathrm{mmol} / \mathrm{L}$ L-Phe plus $0.8 \mu \mathrm{Ci}$ of L-[ring- $\left.2,4-{ }^{3} \mathrm{H}\right]$ Phe and indicated EAA for the measurement of protein synthesis. To determine protein degradation, BMEC were cultured in an -EAA/+EAA DMEM containing 5\% FBS for $2 \mathrm{~d}$ as described above. Subsequently, cells were cultured for $24 \mathrm{~h}$ in $2 \mathrm{~mL}$ of $-\mathrm{EAA} /+\mathrm{EAA}$ DMEM containing $5 \%$ FBS, $0.1 \mathrm{mmol} / \mathrm{L}$ L-Phe plus 0.8 $\mu \mathrm{Ci}$ of $\mathrm{L}-\left[\right.$ ring- $\left.2,4{ }^{3} \mathrm{H}\right] \mathrm{Phe}$ to label cellular proteins. To deplete the intracellular and extracellular free $\left[{ }^{3} \mathrm{H}\right] \mathrm{Phe}$, the cells were washed 3 times with $2 \mathrm{~mL}$ of DMEM (-EAA). The cells were then cultured for $3 \mathrm{~h}$ in $2 \mathrm{~mL}$ of - EAA/+EAA DMEM containing 5\% FBS and 1 $\mathrm{mmol} / \mathrm{L}$ L-Phe to measure the release of $\left[{ }^{3} \mathrm{H}\right] \mathrm{Phe}$ from the labeled protein as an indicator of protein degradation.

\section{Cell Viability Assay}

The analysis of cell viability was determined by cell counting kit-8 (CCK-8, Beyotime). First, BMEC were seeded at $1 \times 10^{5}$ cells/well in a 96-well plate with complete culture medium without $10 \%$ FBS overnight. Then, BMEC were divided into 4 groups and treated as described above. After $24 \mathrm{~h}$ of treatment, the viable cells were identified using a CCK-8 assay as follows: $20 \mu \mathrm{L}$ of CCK-8 solution was added to each well and the 96 -well plates were incubated at $37^{\circ} \mathrm{C}$ in a humidified atmosphere containing $5 \% \mathrm{CO}_{2}$ for an additional $2 \mathrm{~h}$. Finally, spectrophotometric absorbance at $450 \mathrm{~nm}$ was measured with a microplate reader (Spectramax M5, Molecular Devices Corp., San Jose, CA), and the analysis was performed in 6 replicates.

\section{Cell Cycle Assay}

The proportion of BMEC in different cell cycle phases was determined by flow cytometry assay. First, BMEC were plated at $3 \times 10^{5}$ cells/well and incubated in 6 -well culture plates with complete culture medium without $10 \% \mathrm{FBS}$ for at least $24 \mathrm{~h}$ to synchronize the cell cycle. Then, BMEC were divided into 4 groups and treated as the $2 \times 2$ factorial design described above. After 24 $\mathrm{h}$ of treatment, the cells were collected and washed 3 times with PBS. Each group was fixed overnight with ice-cold $70 \%$ ethanol at $4^{\circ} \mathrm{C}$, and washed 3 times with PBS followed by resuspension with PBS containing 0.1 $\mathrm{mg} / \mathrm{mL}$ RNase A (Beyotime) and $5 \mu \mathrm{g} / \mathrm{mL}$ propidium iodide (Beyotime) for $0.5 \mathrm{~h}$ at $37^{\circ} \mathrm{C}$ in the dark, and 3 additional washes with PBS. The cells were subsequently resuspended with $\mathrm{PBS}$ and analyzed using a
FACS Calibur (BDFACS Aria Cell Sorter 334078, Becton Dickinson, Franklin Lakes, NJ). The color intensity of BMEC stained with propidium iodide was measured, and the resulting data were analyzed using Modfit software (version 3.0, Verity Software House, Topsham, ME; Kampa-Schittenhelm et al., 2013).

\section{Statistical Analysis}

All data are expressed as means \pm standard errors of the means. Data for the relative protein abundance of SARS and $\beta$-casein under EAA deprivation or supplement for different durations were statistically analyzed using SAS software (version 9.2; SAS Institute Inc., Cary, NC) using one-way ANOVA with Tukey's multiple range tests, and the significant level was set as $P<0.05$. All other data were statistically analyzed using 2-way ANOVA followed by Bonferroni correction in SAS. The significance level was set at $P<0.05$.

\section{RESULTS}

\section{Effects of Duration of EAA Deprivation and Supplement on Relative Protein Abundance of SARS and $\beta$-Casein in BMEC}

Compared with the NC group (si-NC), the relative mRNA abundance of the SARS gene after si-SARS-4 transfection was most reduced (up to $85 \%$ ) of the 4 sequences of si-SARS transfection (Supplemental Figure S2; https://doi.org/10.3168/jds.2018-14568). Therefore, si-SARS-4 was used in the subsequent studies. When BMEC were first starved of EAA and then resupplied with EAA, the relative protein abundances of SARS and $\beta$-casein were significantly enhanced with increasing EAA resupplement time to $6 \mathrm{~h}$ (Figure 1A and $1 \mathrm{~B}, P<0.05$ ); at $6 \mathrm{~h}$, their protein abundances were maximal. In contrast, when BMEC were first EAA-sufficient followed by EAA deprivation, changes in the protein abundance of SARS and $\beta$-casein showed the opposite pattern; their protein abundances were significantly lower at $6 \mathrm{~h}$ than those at other time points (Figure 1C and 1D).

\section{Effects of EAA Deprivation and Supplement Under SARS Inhibition on Cellular Protein Turnover and $\beta$-Casein Expression}

To examine whether SARS could affect the global protein metabolism, we determined the effects of EAA deprivation and supplementation within SARS inhibition on cellular protein turnover (including protein synthesis and protein degradation). The results of 
A

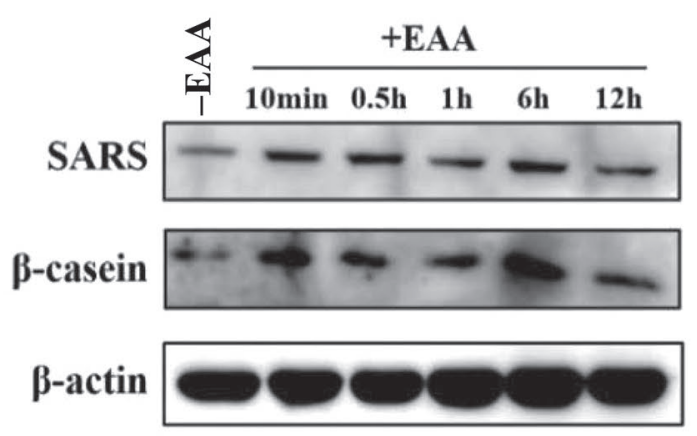

B

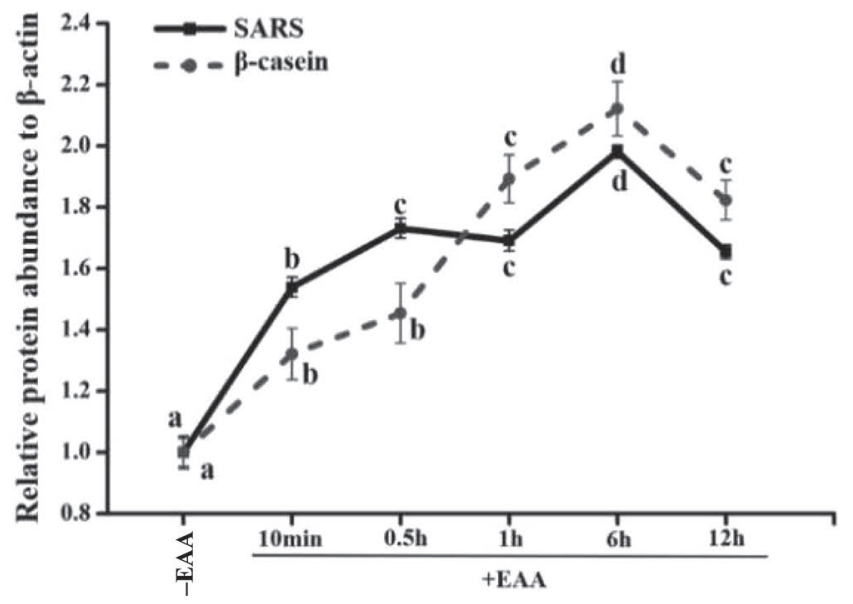

C

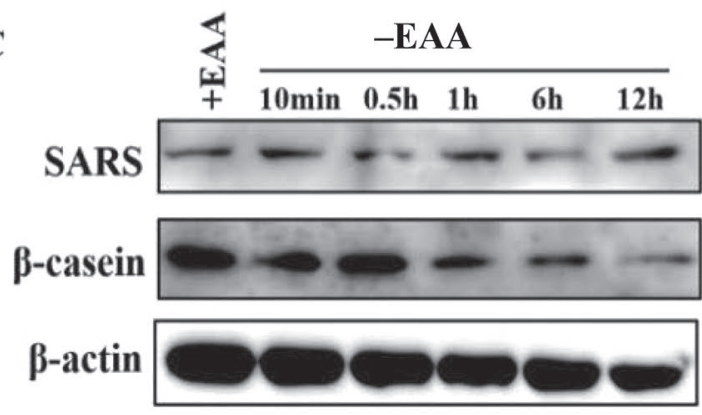

D

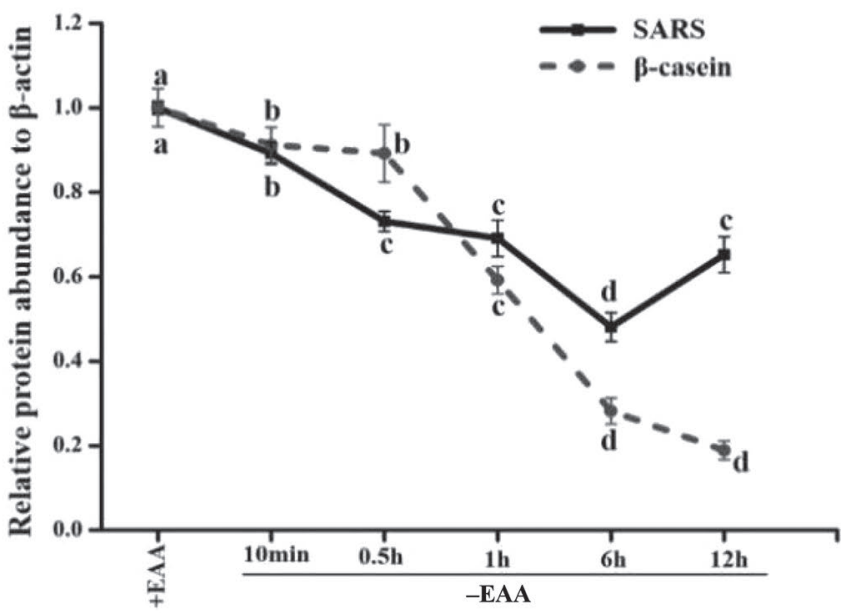

Figure 1. Effects of the time of EAA deprivation and supplement on the relative protein abundance of seryl-tRNA synthetase (SARS) and $\beta$-casein in bovine mammary epithelial cells (BMEC). (A) Western blot and (B) relative protein abundance of SARS and $\beta$-casein in BMEC treated first with EAA starvation (-EAA) for $12 \mathrm{~h}$ and then resupplement of EAA supplement (+EAA) for $10 \mathrm{~min}, 0.5 \mathrm{~h}, 1 \mathrm{~h}, 6 \mathrm{~h}$, or $12 \mathrm{~h}$. (C) Western blot and (D) relative protein abundance of SARS and casein in BMEC treated first with EAA supplement (+EAA) for $12 \mathrm{~h}$ followed by EAA starvation (-EAA) for $10 \mathrm{~min}, 0.5 \mathrm{~h}, 1 \mathrm{~h}, 6 \mathrm{~h}$, or $12 \mathrm{~h}$. In all panels, data represent the mean \pm SEM of 3 independent experiments, and at least 3 wells per treatment within each independent experiment. Data marked with different letters (a-d) represent a significant difference $(P<0.05)$ by one-way ANOVA.

the RNAi treatments combined with EAA deprivation and supplement (Figure $2 \mathrm{~A}$ and $2 \mathrm{~B}$ ) showed that EAA and SARS both significantly stimulated total protein synthesis $\left(P_{\mathrm{EAA}}<0.001, P_{\mathrm{SARS}}<0.001\right)$ but prevented protein degradation $\left(P_{\mathrm{EAA}}<0.001, P_{\mathrm{SARS}}=\right.$ 0.007) compared with those in EAA-deprived/SARS inhibition groups. Moreover, the 2 factors existed with a significant interaction effect on protein degradation in BMECs $\left(P_{\text {interaction }}<0.001\right)$. Furthermore, we also measured the responses of $\beta$-casein under EAA and SARS interaction. We found the protein abundance of SARS was significantly inhibited within the RNA interference $(\mathbf{R N A i})$ treatments $\left(P_{\mathrm{SARS}}=0.0263\right)$, and EAA had a prominent stimulating effect on $\beta$-casein protein abundance $\left(P_{\mathrm{EAA}}=0.0389\right.$; Figure 3$)$. Inhibition of SARS subsequently reduced EAA-stimulated $\beta$-casein synthesis.

To explore the specificity of different tRNA on casein synthesis, we conducted another siRNA experiment with MARS and determined its effects on casein synthesis. The relative mRNA abundance of MARS was significantly depressed within the RNAi treatments $\left(P_{\mathrm{MARS}}=0.0036\right.$; panel A of Supplemental Figure S3; https://doi.org/10.3168/jds.2018-14568). In panel B of Supplemental Figure S3, the EAA-stimulated $\beta$-casein protein abundance was largely reduced by MARS inhibition $\left(P_{\text {MARS }}<0.001\right)$; we also detected an interaction between EAA and MARS $\left(P_{\text {interaction }}<0.001\right)$ on $\beta$-casein synthesis. Additionally, the reduction of EAAstimulated $\beta$-casein protein abundance was greater under MARS inhibition than under SARS inhibition (Figure 3B and Supplemental Figure S3B).

\section{Effects of EAA Deprivation and Supplement Under SARS Inhibition on Cell Viability and Cell Cycle}

As shown in Figure 4, compared with the +EAA group, BMEC viability was significantly depressed 
under the deprivation group (-EAA; $\left.P_{\mathrm{EAA}}<0.001\right)$; this reduction of viability was greater when SARS protein abundance was reduced (si-SARS group; $P_{\text {SARS }}<$ 0.001 ), which may result from the similar effects of interaction between SARS and EAA $\left(P_{\text {interaction }}<0.001\right)$.

In Figure 5, the percentage of mammary cells in the $\mathrm{G}_{1}$ phase was significantly enhanced with -EAA groups compared with +EAA groups (67.87 vs. $48.41 \%$, EAA vs. +EAA; 74.42 vs. $56.25 \%,-$ EAA/si-SARS vs. + EAA/si-SARS; $\left.P_{\mathrm{EAA}}<0.001\right)$, and SARS inhibition further promoted this increase of mammary cells in the $\mathrm{G}_{1}$ phase $\left(P_{\text {SARS }}<0.001\right)$. When $\mathrm{G}_{1}$ phase cells increased, the percentage of mammary cells in $S$ plus $\mathrm{G}_{2}$ phases were decreased. Moreover, EAA and SARS had an interaction effect on $\mathrm{G}_{2}$ and $\mathrm{S}$ phases but not on $\mathrm{G}_{1}$ phase $\left(\mathrm{G}_{1}\right.$ phase, $P_{\text {interaction }}=0.4778 ; \mathrm{S}$ phase, $P_{\text {interaction }}<0.001 ; \mathrm{G}_{2}$ phase, $\left.P_{\text {interaction }}<0.001\right)$.

Additionally, we explored the effects of EAA and SARS on the mRNA abundance of genes related to the cell cycle and cell proliferation. Under EAA deprivation and SARS inhibition, the mRNA abundance of stratifin $(\boldsymbol{S F N})$ was significantly enhanced compared with controls (Figure $6 \mathrm{~A} ; P_{\mathrm{EAA}}<0.001, P_{\mathrm{SARS}}<0.001$, $\left.P_{\text {interaction }}=0.0012\right)$. However, the mRNA abundance of cyclin D1 ( CCND1) and the marker of proliferation Ki-67 (MKI67, marker of cell proliferation) showed the opposite (Figure 6B, 6C).

\section{Effects of EAA Deprivation and Supplement Under SARS Inhibition on Expression of $m$ TOR Signaling in BMEC}

The results in Figure $7 \mathrm{~A}$ and $7 \mathrm{~B}$ showed that the protein abundances of mTOR and S6K1 were not significantly different in +EAA versus -EAA groups $\left(\mathrm{mTOR}, P_{\mathrm{EAA}}=0.0542 ; \mathrm{S} 6 \mathrm{~K} 1, P_{\mathrm{EAA}}=0.077\right)$, but were significantly increased in WT versus si-SARS groups $\left(\mathrm{mTOR}, P_{\mathrm{SARS}}=0.0175 ; \mathrm{S} 6 \mathrm{~K} 1, P_{\mathrm{SARS}}=0.024\right)$. In contrast, the phosphorylated $(\mathbf{p})$ protein abundances of mTOR and S6K1 were significantly enhanced in + EAA versus - EAA groups (p-mTOR, $P_{\mathrm{EAA}}=0.006$; $\mathrm{p}-\mathrm{S} 6 \mathrm{~K} 1$, $\left.P_{\mathrm{EAA}}=0.0389\right)$ and in $\mathrm{WT}$ versus si-SARS groups (p-mTOR, $P_{\text {SARS }}<0.001 ;$ p-S6K1, $P_{\text {SARS }}=0.0263$; Figure $7 \mathrm{~A}$ and $7 \mathrm{~B}$ ). Furthermore, EAA and SARS had an interaction effect on the protein abundance of phosphorylated-mTOR (Figure 7A; $P_{\text {interaction }}=0.016$ ). Meanwhile, the protein abundances of $4 \mathrm{EBP} 1$ and its phosphorylated protein (Figure 7C) were significantly enhanced in + EAA versus - EAA groups $\left(4 \mathrm{EBP} 1, P_{\mathrm{EAA}}\right.$ $\left.<0.001 ; \mathrm{p}-4 \mathrm{EBP} 1, P_{\mathrm{EAA}}<0.001\right)$ and in WT versus siSARS groups (4EBP1, $P_{\text {SARS }}<0.001 ;$ p- $4 \mathrm{EBP} 1, P_{\mathrm{SARS}}$ $<0.001)$; again, EAA and SARS had an interaction influence on the protein abundances of $4 \mathrm{EBP} 1$ and its phosphorylated protein (Figure 7C; 4EBP1, $P_{\text {interaction }}$ $\left.=0.012 ; \mathrm{p}-4 \mathrm{EBP} 1, P_{\text {interaction }}=0.0146\right)$. Figure $7 \mathrm{D}$ also
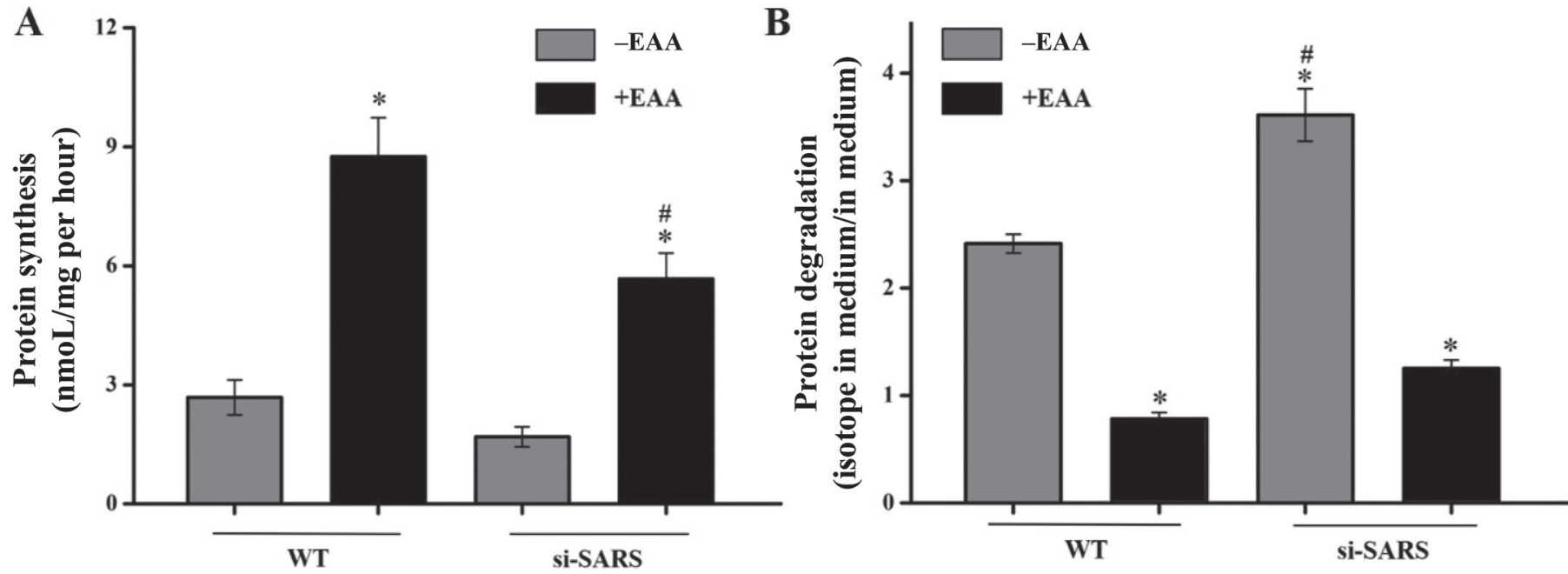

Figure 2. Effects of EAA deprivation and supplement under seryl-tRNA synthetase (SARS) inhibition on (A) cellular protein synthesis (2-way ANOVA: $\left.P_{\mathrm{EAA}}<0.001, P_{\mathrm{SARS}}<0.001, P_{\text {interaction }}=0.059\right)$, and $(\mathrm{B})$ protein degradation $\left(2\right.$-way ANOVA: $P_{\mathrm{EAA}}<0.001, P_{\mathrm{SARS}}=0.007$, $\left.P_{\text {interaction }}<0.001\right)$ in bovine mammary epithelial cells $(\mathrm{BMEC}) .{ }^{*} P$-value $<0.05$ versus $-\mathrm{EAA}$ and $\# P$-value $<0.05$ versus wild-type $(\mathrm{WT})$. The BMEC were treated with EAA deprivation and supplement under SARS inhibition for $2 \mathrm{~d}$, and then protein synthesis and protein degradation were determined using a stable isotope labeling method. Wild-type (WT) indicates BMEC were transfected with negative control siRNA; siSARS indicates BMEC were transfected with RNAi interference of SARS gene. In all panels, data represent the mean \pm SEM of 3 independent experiments and at least 3 wells per treatment within each independent experiment. 
shows changes in the relative phosphorylation ratios (p$\mathrm{mTOR} / \mathrm{mTOR}$, p-S6K1/S6K1, and p-4EBP1/4EBP1) in response to EAA supplement and SARS inhibition, which showed the same trends as those of their phosphorylated proteins (p-mTOR, p-S6K1, and p-4EBP1); meanwhile, EAA and SARS exerted an interaction effect on relative phosphorylation ratios (p-mTOR/ mTOR, $P_{\text {interaction }}=0.033 ; \mathrm{p}-4 \mathrm{EBP} 1 / 4 \mathrm{EBP} 1, P_{\text {interaction }}$ $=0.005)$.

\section{DISCUSSION}

In ruminants, AA could promote mammary cell proliferation and milk protein synthesis primarily through their regulation of the mTORC1 pathway (Bruhat et al., 2009; Appuhamy et al., 2012; Arriola Apelo et al., 2014; Rezaei et al., 2016; Luo et al., 2018). Although the critical role of the mTOR system in EAA regulating milk protein synthesis in human and rodents is well characterized, a greater understanding of the process in ruminants is needed. To date, potential functional roles of AARS involved in AA regulating milk protein synthesis have been identified in humans (Han et al., 2012) and dairy cows (Wang et al., 2014). Furthermore, SARS has been shown to be closely related to lactation in dairy cows that were fed different roughages (Dai et al., 2017a) or during varying lactation periods (Dai et al., 2017b, 2018). Therefore, the present find-

A

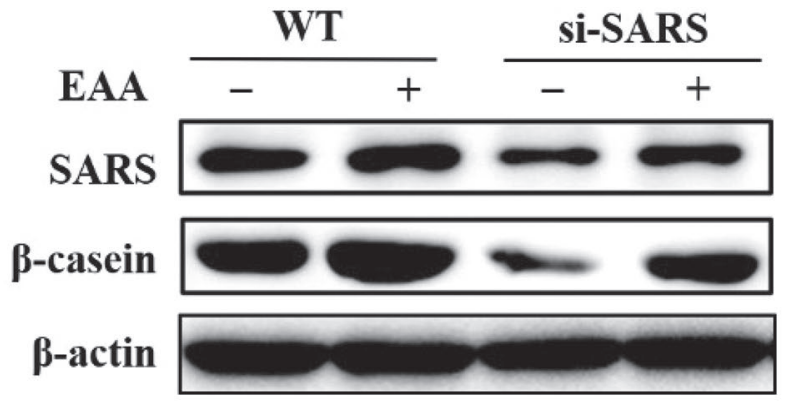

B

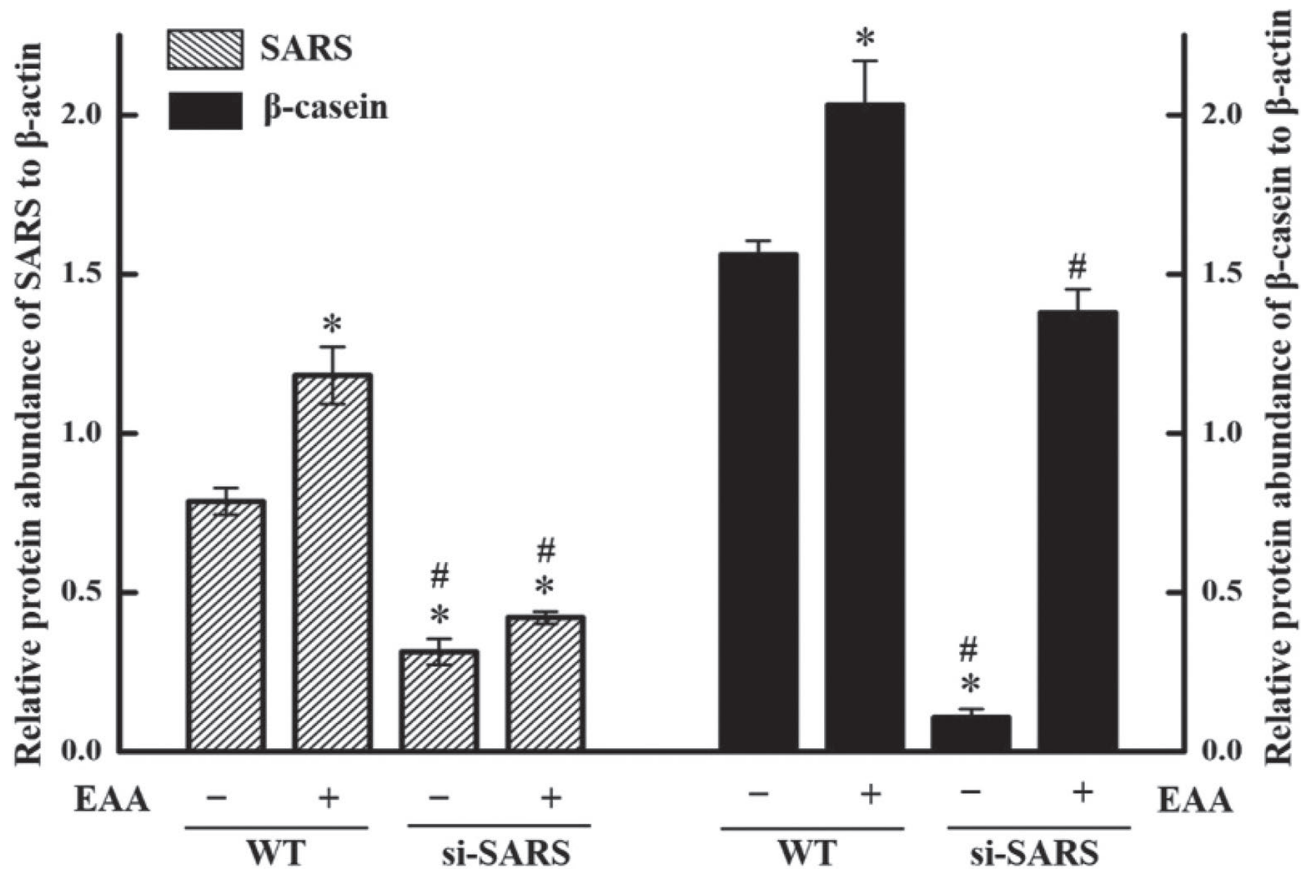

Figure 3. Effects of EAA deprivation and supplement under seryl-tRNA synthetase (SARS) inhibition on the relative protein abundance of SARS (2-way ANOVA: $\left.P_{\mathrm{EAA}}=0.0389, P_{\mathrm{SARS}}=0.0263, P_{\text {interaction }}=0.8738\right)$ and $\beta$-casein $\left(2\right.$-way ANOVA: $P_{\mathrm{EAA}}<0.001, P_{\mathrm{SARS}}<0.001, P_{\text {interaction }}$ $=0.006)$ in bovine mammary epithelial cells (BMEC). ${ }^{*} P$-value $<0.05$ versus - EAA and $\# P$-value $<0.05$ versus wild-type $(\mathrm{WT})$. The treatment time of EAA deprivation and supplement was $6 \mathrm{~h}$. $\beta$-Actin was the internal reference protein. A representative blot and quantitation of 3 independent experiments are shown. Wild-type (WT) indicates BMEC were transfected with negative control siRNA; si-SARS indicates BMEC were transfected with RNAi interference of SARS gene. In all panels, data represent the mean \pm SEM of 3 independent experiments and at least 3 wells per treatment within each independent experiment. 
ings support the association of SARS with milk protein synthesis in response to EAA.

The markedly enhanced (decreased) expression of SARS and $\beta$-casein and the increase (decrease) of EAA re-stimulation (re-deprivation) time suggest that EAA affected the protein abundance of SARS and $\beta$-casein in similar patterns and that these effects were timedependent. As Luo et al. (2018) reported, when BMEC were first treated with AA deprivation and then resupplied with AA or EAA for the same durations as in this study, the protein abundance of mTOR at the lysosomal outer surface of BMEC (indication of mTOR activation) was gradually enhanced along with the increase of AA or EAA treatment time, which reached the maximum at $6 \mathrm{~h}$ of $\mathrm{AA} / \mathrm{EAA}$ treatment. Therefore, the activation of the mTOR system may be altered along with different treatment time of EAA deficiency and EAA sufficiency. Interestingly, these EAA treatmenttime-dependent mTOR activation may further result in a similar time-dependency pattern as $\beta$-casein synthesis in BMEC under EAA deficiency and EAA sufficiency. Additional work will be required to assess the similar EAA-time-dependent effects of SARS production and its association with $\beta$-casein synthesis in BMEC.

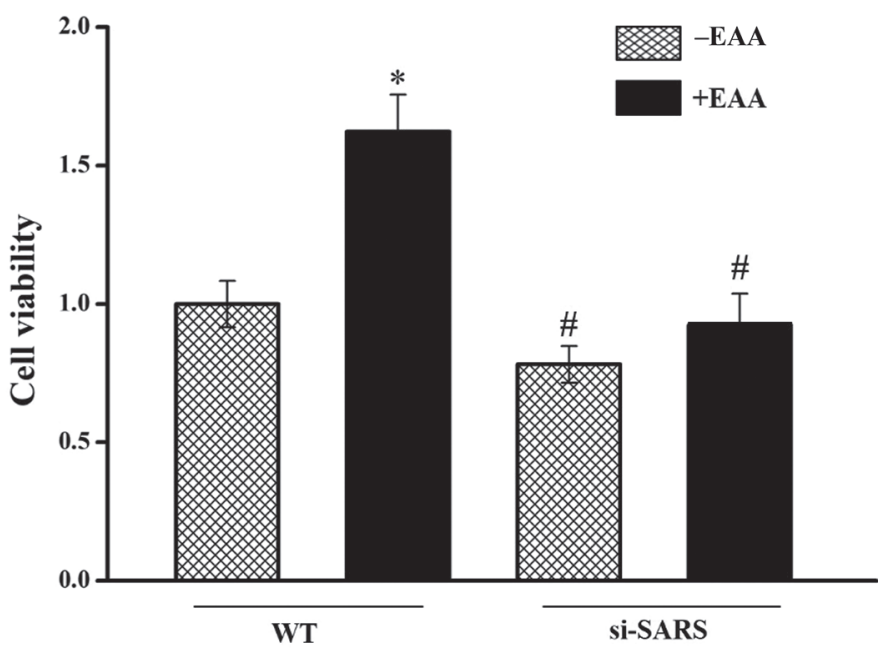

Figure 4. Effects of EAA deprivation and supplement under seryltRNA synthetase (SARS) inhibition on the cell proliferation (2-way ANOVA: $\left.P_{\mathrm{EAA}}<0.001, P_{\mathrm{SARS}}<0.001, P_{\text {interaction }}<0.001\right)$ in bovine mammary epithelial cells (BMEC). ${ }^{*} P$-value $<0.05$ versus - EAA and $\# P$-value $<0.05$ versus wild-type $(\mathrm{WT})$. The BMEC were treated with EAA deprivation and supplement under SARS inhibition for $24 \mathrm{~h}$, and then viable cells were determined by using a cell counting kit. Wildtype (WT) indicates BMEC were transfected with negative control siRNA; si-SARS indicates BMEC were transfected with RNAi interference of SARS gene. In all panels, data represent the mean \pm SEM of 3 independent experiments and 6 wells per treatment within each independent experiment. The cell viability of the -EAA/WT group was regarded as the control and considered to be 1 (mean \pm SEM, 1.0 $\pm 0.065)$.
To further elucidate the function of SARS in milk protein regulation, a silencing system of RNAi was used in this study. Despite the lasting si-RNA-mediated gene silencing through lentiviral-mediated and adenoviral-mediated expression systems (Abbas-Terki et al., 2002), a transient gene silencing method via lipofectamine-mediated expression system was still widely used for its simplicity and efficiency within 48 to $72 \mathrm{~h}$ after RNAi transfection. For example, Han et al. (2012) and Wang et al. (2014) separately used LARS-specific siRNA transfection in human 293T cells and in primary BMEC; 48 h later, gene expression of LARS was largely suppressed. In the current study, a lipofectamine reagent method was used to transfect 4 RNAi of SARS sequence into BMEC, and the maximum reduction in gene expression of $S A R S$ was achieved by si-SARS-4 transfection, indicating that gene expression of $S A R S$ in BMEC was effectively inhibited by si-SARS-4 transfection. Therefore, the sequence of si-SARS-4 was used to suppress the gene and protein expression of SARS in the study.

Here, SARS inhibition reduced EAA-stimulated protein abundance of $\beta$-casein and protein turnover (protein synthesis increased and protein degradation decreased), illustrating a crucial role of SARS in the promotion of protein metabolism, especially casein synthesis. This finding is in accordance with the lower abundance of $\beta$-casein under LARS inhibition in BMEC (Wang et al., 2014). Additionally, with EAA supplementation and deprivation, the relative protein abundance of $\beta$-casein in BMEC was reduced to a greater degree under MARS inhibition than under SARS inhibition, which may be expected because Met and its corresponding tRNA (Met-tRNAi) initiated the translation. These results suggest different tRNA synthetases and various AA types exert their specific effects on casein synthesis.

As this potential association of SARS with milk protein synthesis indicates, it is important to better understand the functional mechanism of SARS in milk protein production. Mammary cell population is an essential regulatory factor for milk yield (including milk protein yield; Ellis and Capuco, 2002; Theodorou et al., 2011). Therefore, it is essential to evaluate whether SARS could affect EAA-stimulated $\beta$-casein production by regulating mammary cell population. Compared with the EAA-deprivation and SARS knockdown (si-SARS) groups, the higher mammary cell viability within the EAA-supplement and WT groups was in line with EAA-stimulated mammary cell viability (Luo et al., 2018) and LARS-promoted cell proliferation in BMEC (Wang et al., 2014). Overall, EAA and SARS had similar stimulating effects on cell viability for BMEC, and the subsequent enhanced cell viability 
A
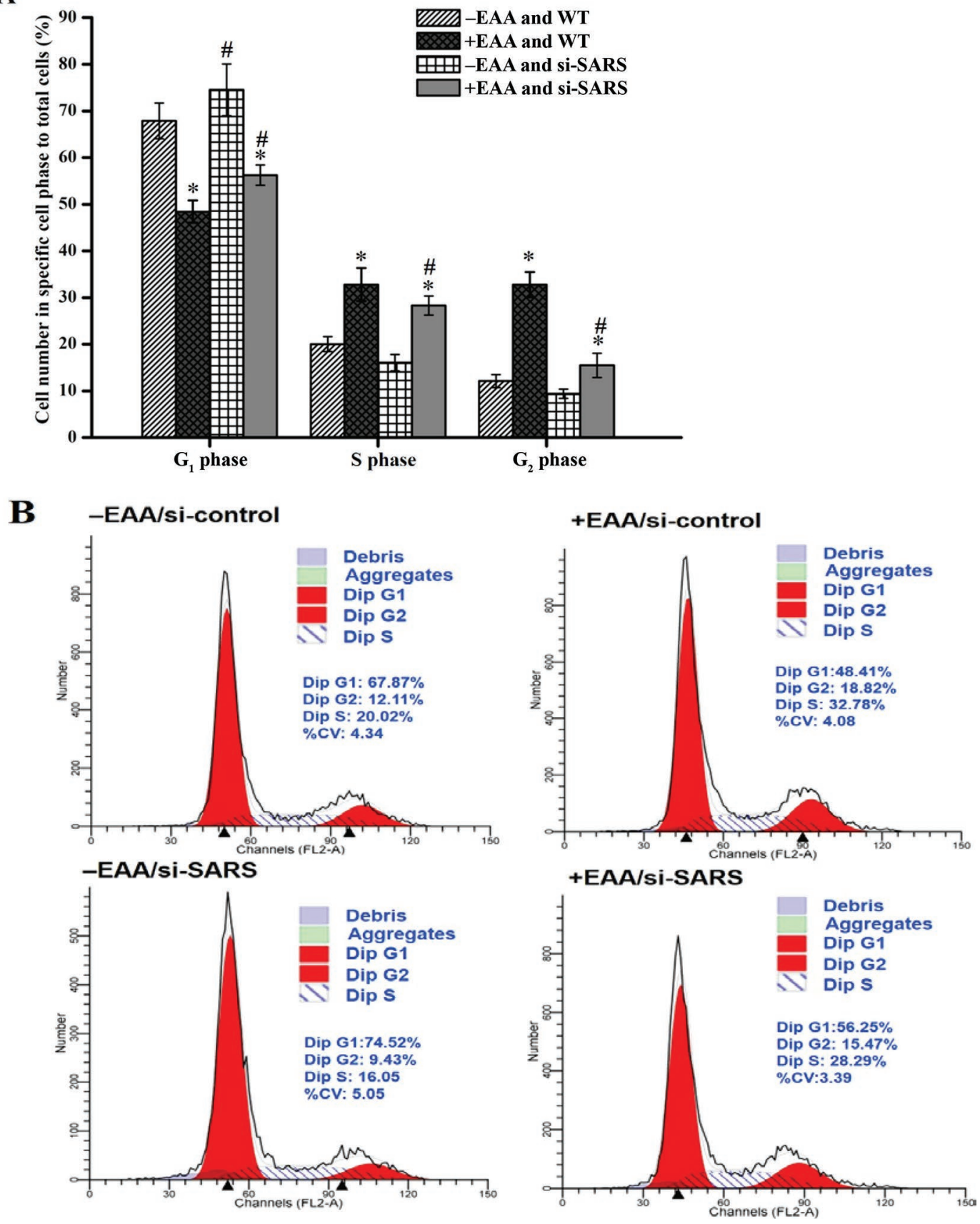

Figure 5. Effects of EAA deprivation and supplement under seryl-tRNA synthetase (SARS) inhibition on the percentages of cell in different cell phases compared with the total cells in bovine mammary epithelial cells (BMEC) (A) $\left(2\right.$-way ANOVA: $\mathrm{G}_{1}$ phase, $P_{\mathrm{EAA}}<0.001, P_{\mathrm{SARS}}$ $<0.001, P_{\text {interaction }}=0.4778 ; \mathrm{S}$ phase, $P_{\mathrm{EAA}}=0.003, P_{\mathrm{SARS}}<0.01, P_{\text {interaction }}<0.001 ;$ and $\mathrm{G}_{2}$ phase, $P_{\mathrm{EAA}}<0.001, P_{\mathrm{SARS}}<0.001, P_{\text {interaction }}<$ $0.001)$ in BMEC. ${ }^{*} P$-value $<0.05$ versus - EAA and $\# P$-value $<0.05$ versus wild-type $(\mathrm{WT})$. (B) Measurement of the cell cycle progression by flow cytometric analysis of propidium iodide-stained BMEC after treatments of EAA deprivation and supplement under SARS inhibition for $24 \mathrm{~h}$. Wild-type (WT) indicates BMEC were transfected with negative control siRNA; si-SARS indicates BMEC were transfected with RNAi interference of SARS gene. Representative histograms and quantitation of 3 cell-cycle independent experiments are shown. In all panels, data represent the mean \pm SEM of 3 independent experiments and at least 3 wells per treatment within each independent experiment. Dip $=$ diploid. Color version available online.

would help generate more mammary cells and thus more milk. Also, the markedly enhanced shift toward cell cycle progression suggests that SARS promotes the EAA-stimulated cell cycle of BMEC, resulting in a higher mammary cell number and likely contributing to increased casein synthesis. 


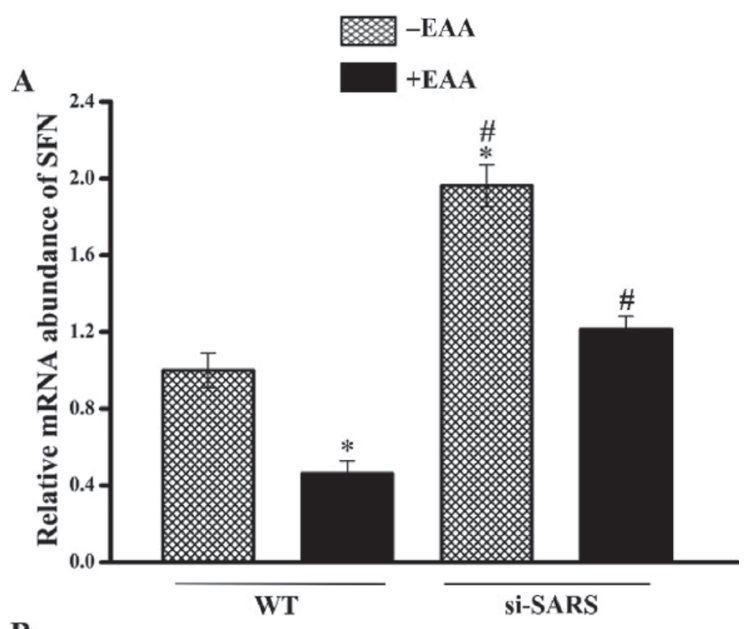

B

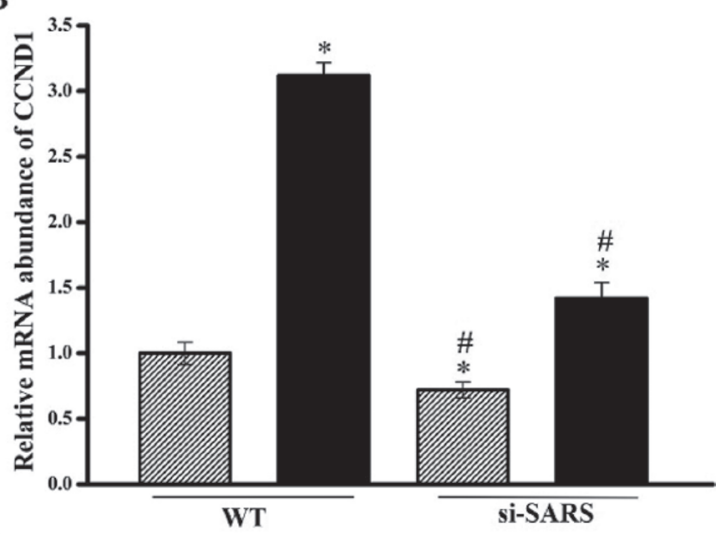

C

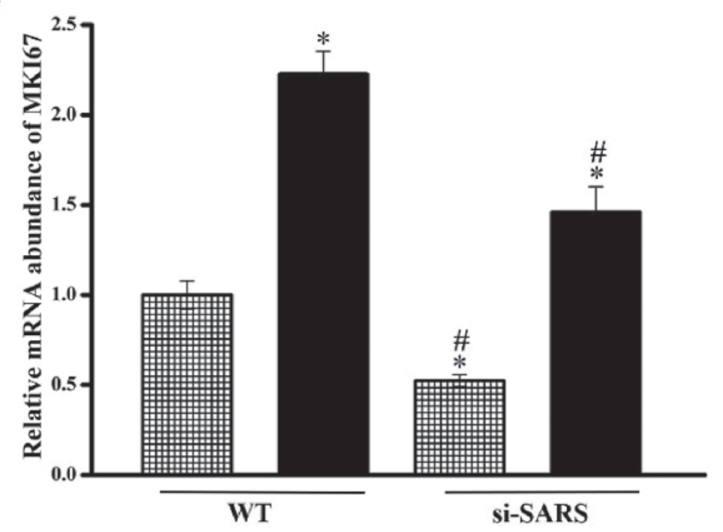

Figure 6. Effects of EAA deprivation and supplement under seryltRNA synthetase (SARS) inhibition on relative mRNA abundance of genes (A) $S F N$ (2-way ANOVA: $P_{\mathrm{EAA}}<0.001, P_{\mathrm{SARS}}<0.001, P_{\mathrm{i}}$ $=0.012$ ); (B) CCND1 (2-way ANOVA: $P_{\mathrm{EAA}}<0.001, P_{\mathrm{SARS}}<0.001$, $\left.P_{\text {interaction }}=0.005\right)$; and $(\mathrm{C})$ MKI67 $\left(2\right.$-way ANOVA: $P_{\mathrm{EAA}}<0.001$, $\left.P_{\mathrm{SARS}}<0.001, P_{\text {interaction }}=0.008\right)$ in bovine mammary epithelial cells (BMEC). ${ }^{*} P$-value $<0.05$ versus - EAA and $\# P$-value $<0.05$ versus wild-type (WT). Wild-type (WT) indicates BMEC were transfected with negative control siRNA; si-SARS indicates BMEC were transfected with RNAi interference of SARS gene. The BMEC were treated with EAA deprivation and supplement under SARS inhibition for $6 \mathrm{~h}$, and the relative mRNA abundance of the 3 genes was determined by using quantitative real-time-PCR. The RPS9 and KRT8 genes act as the internal reference genes. In all panels, data represent the mean \pm SEM of 3 independent experiments and at least 3 wells per treatment within each independent experiment.
Enhanced expression of cell proliferation and growth markers and lower expression of cell cycle arrest markers was observed within BMEC in this study. As an epithelial marker, the 14-3-3 $\delta$ protein (encoded by $S F N$ ) is a negative regulator of the cell cycle and is upregulated in response to DNA damage in a number of epithelial phenotypes (including mammary epithelial cells) to arrest cells at the $\mathrm{G}_{1}$ and $\mathrm{G}_{2} / \mathrm{M}$ checkpoints (Hermeking and Benzinger, 2006; Gardino and Yaffe, 2011; Thomas et al., 2011). The cyclin-dependent kinases are critical in regulating cell cycle progression, and cyclin D1, specifically, is known to promote $G_{1} / S$ phase transition in several types of cells ( $\mathrm{Du}$ et al., 2013; Sales et al., 2014; Casimiro et al., 2015). The precise function of the Ki67 protein (encoded by $M K I 6^{n}$ ), expressed during all phases of the cell cycle except $\mathrm{G}_{0}$, is uncertain; however, several studies have established that the protein acts as a robust marker of proliferating cells (Ayoub et al., 2013) and the gene expression of MKI67 provides an estimation of the mammary tissue growth (Capuco et al., 2001). In the current study, the stimulating effects of EAA and SARS led to enhanced cell viability or cell proliferation $\left(M K I 6^{7}\right) /$ cell cycle progression $(C C N D 1)$ and lower cell cycle arrest $(S F N)$ in BMEC. The overall results confirm earlier findings that EAA sufficiency (Luo et al., 2018) and LARS (Wang et al., 2014) promote cell viability, cell cycle, and $\beta$-casein production in BMEC. In summary, SARS may help EAA accelerate cell cycle progression of BMEC, which could further promote mammary cell population expansion and increase milk production.

The activation of the mTORC1 signaling pathway in response to EAA is critical for the regulation of protein synthesis in mammals (Jewell and Guan, 2013; Kim et al., 2013). Furthermore, mTORC1 is critical for milk protein synthesis in dairy cows (Appuhamy et al., 2011; Li et al., 2017). Additionally, phosphorylation of S6K1 and 4EBP1 was demonstrated previously as a marker of mTOR activation (Hara et al., 1998). The increased phosphorylation of mTOR and its downstream factors (S6K1 and 4EBP1) stimulated by EAA confirmed the regulatory effects of EAA on promotion of milk protein synthesis by motivating the mTOR signaling pathway in BMEC. Additionally, these changes in mTOR-related protein abundance in response to EAA are in line with previous studies conducted in MAC-T cells (Appuhamy et al., 2011), bovine mammary gland tissue explants ( $\mathrm{Li}$ et al., 2017), and BMEC (Gao et al., 2015). It appears that SARS inhibition blocks the stimulating effects of EAA on the mTOR system and then prevents casein synthesis. This finding is supported by previous work on LARS, which identified LARS inhibition-induced inactivation of the mTOR signaling pathway in response to leucine (Han et al., 2012; Wang et al., 2014). Col- 

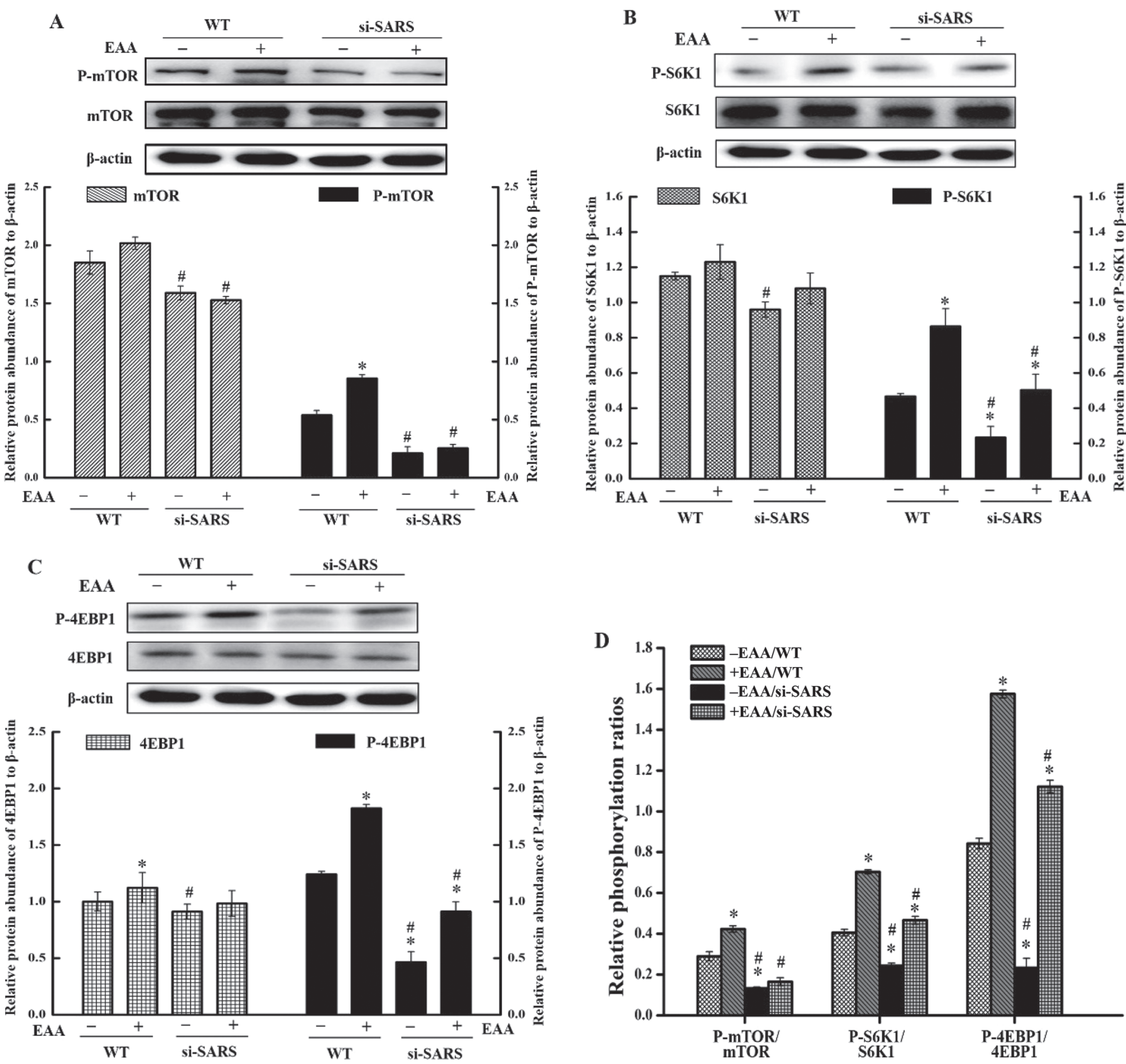

Figure 7. Effects of EAA deprivation and supplement under seryl-tRNA synthetase (SARS) inhibition on the relative protein abundance of proteins involved in mammalian target or rapamycin (mTOR) signaling in bovine mammary epithelial cells (BMEC). Relative protein expression of $(\mathrm{A}) \mathrm{mTOR}\left(2\right.$-way ANOVA: $\left.P_{\mathrm{EAA}}=0.0542, P_{\mathrm{SARS}}=0.0175, P_{\text {interaction }}=0.1198\right)$ and phosphorylated $(\mathrm{p})$-mTOR $\left(2\right.$-way ANOVA: $P_{\mathrm{EAA}}$ $\left.=0.006, P_{\mathrm{SARS}}<0.001, P_{\text {interaction }}=0.016\right) ;(\mathrm{B}) \mathrm{S} 6 \mathrm{~K} 1\left(2\right.$-way ANOVA: $\left.P_{\mathrm{EAA}}=0.077, P_{\mathrm{SARS}}=0.024, P_{\text {interaction }}=0.6511\right)$ and phosphorylated S6K1 (2-way ANOVA: $\left.P_{\mathrm{EAA}}=0.0389, P_{\mathrm{SARS}}=0.0263, P_{\text {interaction }}=0.8738\right)$; and $(\mathrm{C})$ 4EBP1 $\left(2\right.$-way ANOVA: $P_{\mathrm{EAA}}<0.001, P_{\mathrm{SARS}}=0.0561$, $\left.P_{\text {interaction }}=0.012\right)$ and phosphorylated 4EBP1 (2-way ANOVA: $\left.P_{\text {EAA }}<0.001, P_{\text {SARS }}<0.001, P_{\text {interaction }}=0.0146\right)$ analyzed by Western blotting in BMEC treated with EAA deprivation and supplement under SARS inhibition. (D) The phosphorylation ratios of mTOR (2-way ANOVA: $\left.P_{\mathrm{EAA}}=0.004, P_{\mathrm{SARS}}<0.001, P_{\text {interaction }}=0.033\right)$, S6K1 $\left(2\right.$-way ANOVA: $\left.P_{\mathrm{EAA}}<0.001, P_{\mathrm{SARS}}<0.001, P_{\text {interaction }}=0.1289\right)$ and $4 \mathrm{EBP} 1(2$-way ANOVA: $\left.P_{\mathrm{EAA}}<0.001, P_{\mathrm{SARS}}<0.001, P_{\text {interaction }}=0.005\right)$ to their corresponding phosphorylated proteins in BMEC treated with EAA deprivation and supplement under SARS inhibition. ${ }^{*} P$-value $<0.05$ versus - EAA and $\# P$-value $<0.05$ versus wild-type (WT). The treatment time of EAA deprivation and supplement was $6 \mathrm{~h}$. $\beta$-Actin was the internal reference protein. A representative blot and quantitation of 3 independent experiments are shown. Wild-type (WT) indicates BMEC were transfected with negative control siRNA; si-SARS indicates BMEC were transfected with RNAi interference of SARS gene. In all panels, data represent the mean \pm SEM of 3 independent experiments and at least 3 wells per treatment within each independent experiment. 
lectively, the evidence indicates that a close association exists among SARS, the mTOR signaling pathway, and casein synthesis. The detailed regulatory mechanism of SARS in regulating milk protein synthesis of ruminants mammary cells remains to be further clarified.

\section{CONCLUSIONS}

The present work showed that SARS acts as an important positive regulatory factor mediating the relationship between EAA and $\beta$-casein synthesis through cell proliferation (cell viability and cell cycle progression) and activation of the mTOR pathway in BMEC. This finding provides a target for future investigation of the mTOR system in the mammary gland of dairy cows.

\section{ACKNOWLEDGMENTS}

This research was supported by grants from the National Natural Science Foundations of China (31672447, 31872989). The authors gratefully thank the personnel of Hangjiang Dairy Farm (Hangzhou, China) for their assistance in the feeding and care of the animals. The procedures of this study were approved by the Animal Care and Use Committee of Zhejiang University (Hangzhou, China) and were in accordance with the university's guidelines for animal research. The authors declare that they have no conflict of interest.

\section{REFERENCES}

Abbas-Terki, T., W. Blanco-Bose, N. Déglon, W. Pralong, and P. Aebischer. 2002. Lentiviral-mediated RNA interference. Hum. Gene Ther. 13:2197-2201.

Appuhamy, J. A., A. L. Bell, W. A. Nayananjalie, J. Escobar, and M. D. Hanigan. 2011. Essential amino acids regulate both initiation and elongation of mRNA translation independent of insulin in MAC-T cells and bovine mammary tissue slices. J. Nutr. 141:1209-1215.

Appuhamy, J. A., N. A. Knoebel, W. A. Nayananjalie, J. Escobar, and M. D. Hanigan. 2012. Isoleucine and leucine independently regulate mTOR signaling and protein synthesis in MAC-T cells and bovine mammary tissue slices. J. Nutr. 142:484-491.

Appuhamy, J. A., W. A. Nayananjalie, E. M. England, D. E. Gerrard, R. M. Akers, and M. D. Hanigan. 2014. Effects of AMP-activated protein kinase (AMPK) signaling and essential amino acids on mammalian target of rapamycin (mTOR) signaling and protein synthesis rates in mammary cells. J. Dairy Sci. 97:419-429.

Arendt, L. M., and C. Kuperwasser. 2015. Form and function: How estrogen and progesterone regulate the mammary epithelial hierarchy. J. Mammary Gland Biol. Neoplasia 20:9-25.

Arriola Apelo, S. I., L. M. Singer, W. K. Ray, R. F. Helm, X. Y. Lin, M. L. McGilliard, N. R. St-Pierre, and M. D. Hanigan. 2014. Casein synthesis is independently and additively related to individual essential amino acid supply. J. Dairy Sci. 97:2998-3005.

Ayoub, N. M., M. R. Akl, and P. W. Sylvester. 2013. Combined gamma-tocotrienol and Met inhibitor treatment suppresses mammary cancer cell proliferation, epithelial-to-mesenchymal transition and migration. Cell Prolif. 46:538-553.
Bequette, B. J., C. E. Kyle, L. A. Crompton, V. Buchan, and M. D. Hanigan. 2001. Insulin regulates milk production and mammary gland and hind-leg amino acid fluxes and blood flow in lactating goats. J. Dairy Sci. 84:241-255.

Bruhat, A., Y. Cherasse, C. Chaveroux, A. C. Maurin, C. Jousse, and P. Fafournoux. 2009. Amino acids as regulators of gene expression in mammals: Molecular mechanisms. Biofactors 35:249-257.

Burgos, S. A., M. Dai, and J. P. Cant. 2010. Nutrient availability and lactogenic hormones regulate mammary protein synthesis through the mammalian target of rapamycin signaling pathway. J. Dairy Sci. 93:153-161.

Capuco, A. V., D. L. Wood, R. Baldwin, K. McLeod, and M. J. Paape. 2001. Mammary cell number, proliferation, and apoptosis during a bovine lactation: Relation to milk production and effect of bST. J. Dairy Sci. 84:2177-2187.

Casimiro, M. C., G. Di Sante, M. Crosariol, E. Loro, W. Dampier, A. Ertel, Z. Yu, E. A. Saria, A. Papanikolaou, Z. Li, C. Wang, S. Addya, M. P. Lisanti, P. Fortina, R. D. Cardiff, A. Tozeren, E. S. Knudsen, A. Arnold, and R. G. Pestell. 2015. Kinase-independent role of cyclin D1 in chromosomal instability and mammary tumorigenesis. Oncotarget 6:8525-8538.

Collier, R. J., C. M. Stiening, B. C. Pollard, M. J. VanBaale, L. H. Baumgard, P. C. Gentry, and P. M. Coussens. 2006. Use of gene expression microarrays for evaluating environmental stress tolerance at the cellular level in cattle. J. Anim. Sci. 84(Suppl.):E1E13.

Dai, W. T., Q. Chen, Q. J. Wang, R. R. White, J. X. Liu, and H. Y. Liu. 2017a. Complementary transcriptomic and proteomic analyses reveal regulatory mechanisms of milk protein production in dairy cows consuming different forages. Sci. Rep. 7:44234.

Dai, W. T., Q. J. Wang, Y. X. Zou, R. R. White, J. X. Liu, and H. Y. Liu. 2017b. Short communication: Comparative proteomic analysis of the lactating and nonlactating bovine mammary gland. J. Dairy Sci. 100:5928-5935.

Dai, W. T., Y. X. Zou, R. R. White, J. X. Liu, and H. Y. Liu. 2018. Transcriptomic profiles of the bovine mammary gland during lactation and the dry period. Funct. Integr. Genomics 18:125-140.

Du, Z., X. Tong, and X. Ye. 2013. Cyclin D1 promotes cell cycle progression through enhancing NDR1/2 kinase activity independent of cyclin-dependent kinase 4. J. Biol. Chem. 288:26678-26687.

Ellis, S., and A. V. Capuco. 2002. Cell proliferation in bovine mammary epithelium: Identification of the primary proliferative cell population. Tissue Cell 34:155-163.

Gao, H. N., H. Hu, N. Zheng, and J. Q. Wang. 2015. Leucine and histidine independently regulate milk protein synthesis in bovine mammary epithelial cells via mTOR signaling pathway. J. Zhejiang Univ. Sci. B 16:560-572.

Gardino, A. K., and M. B. Yaffe. 2011. 14-3-3 proteins as signaling integration points for cell cycle control and apoptosis. Semin. Cell Dev. Biol. 22:688-695.

Guo, C. L., Y. T. Li, X. Y. Lin, M. D. Hanigan, Z. G. Yan, Z. Y. Hu, Q. L. Hou, F. G. Jiang, and Z. H. Wang. 2017. Effects of graded removal of lysine from an intravenously infused amino acid mixture on lactation performance and mammary amino acid metabolism in lactating goats. J. Dairy Sci. 100:4552-4564.

Han, J. M., S. J. Jeong, M. C. Park, G. Kim, N. H. Kwon, H. K. Kim, S. H. Ha, S. H. Ryu, and S. Kim. 2012. Leucyl-tRNA synthetase is an intracellular leucine sensor for the mTORC1-signaling pathway. Cell 149:410-424.

Hara, K., K. Yonezawa, Q. P. Weng, M. T. Kozlowski, C. Belham, and J. Avruch. 1998. Amino acid sufficiency and mTOR regulate p70 S6 kinase and eIF-4E BP1 through a common effector mechanism. J. Biol. Chem. 273:14484-14494.

Hermeking, H., and A. Benzinger. 2006. 14-3-3 proteins in cell cycle regulation. Semin. Cancer Biol. 16:183-192.

Hu, H., Y. Zhang, N. Zheng, J. Cheng, and J. Wang. 2016. The effect of heat stress on gene expression and synthesis of heat-shock and milk proteins in bovine mammary epithelial cells. Anim. Sci. J. $87: 84-91$

Jewell, J. L., and K. L. Guan. 2013. Nutrient signaling to mTOR and cell growth. Trends Biochem. Sci. 38:233-242. 
Kampa-Schittenhelm, K. M., M. C. Heinrich, F. Akmut, K. H. Rasp, B. Illing, H. Dohner, K. Dohner, and M. M. Schittenhelm. 2013. Cell cycle-dependent activity of the novel dual PI3K-MTORC1/2 inhibitor NVP-BGT226 in acute leukemia. Mol. Cancer 12:46.

Kim, S. G., G. R. Buel, and J. Blenis. 2013. Nutrient regulation of the mTOR complex 1 signaling pathway. Mol. Cells 35:463-473.

Kyriacou, S. V., and M. P. Deutscher. 2008. An important role for the multienzyme aminoacyl-tRNA synthetase complex in mammalian translation and cell growth. Mol. Cell 29:419-427.

Li, S. S., J. J. Loor, H. Y. Liu, L. Liu, A. Hosseini, W. S. Zhao, and J. X. Liu. 2017. Optimal ratios of essential amino acids stimulate beta-casein synthesis via activation of the mammalian target of rapamycin signaling pathway in MAC-T cells and bovine mammary tissue explants. J. Dairy Sci. 100:6676-6688.

Livak, K. J., and T. D. Schmittgen. 2001. Analysis of relative gene expression data using real-time quantitative PCR and the $2(\mathrm{~T})$ (-Delta Delta C) method. Methods 25:402-408.

Luo, C. C., S. G. Zhao, M. C. Zhang, Y. N. Gao, J. Q. Wang, M D. Hanigan, and N. Zheng. 2018. SESN2 negatively regulates cell proliferation and casein synthesis by inhibition the amino acidmediated mTORC1 pathway in cow mammary epithelial cells. Sci. Rep. 8:3912.

Pang, Y. L., K. Poruri, and S. A. Martinis. 2014. tRNA synthetase: tRNA aminoacylation and beyond. RNA 5:461-480.

Park, S. G., P. Schimmel, and S. Kim. 2008. Aminoacyl tRNA synthetases and their connections to disease. Proc. Natl. Acad. Sci. USA 105:11043-11049.

Rezaei, R., Z. Wu, Y. Hou, F. W. Bazer, and G. Wu. 2016. Amino acids and mammary gland development: Nutritional implications for milk production and neonatal growth. J. Anim. Sci. Biotechnol. $7: 20$.
Sales, K. U., F. S. Giudice, R. M. Castilho, F. T. Salles, C. H. Squarize, A. C. Abrahao, and D. S. Pinto Jr.. 2014. Cyclin D1-induced proliferation is independent of beta-catenin in head and neck cancer. Oral Dis. 20:e42-e48.

Shimobayashi, M., and M. N. Hall. 2014. Making new contacts: The mTOR network in metabolism and signalling crosstalk. Nat. Rev. Mol. Cell Biol. 15:155-162.

Theodorou, G., C. Pecorini, R. Rebucci, F. Saccone, C. Lecchi, I. Politis, and A. Baldi. 2011. Effect of growth factors and lactogenic hormones on expression of plasminogen activator-related genes and cell proliferation in a bovine mammary epithelial cell line. J. Dairy Res. 78:365-372.

Thomas, E., N. Zeps, M. Cregan, P. Hartmann, and T. Martin. 2011. 14-3-3sigma (sigma) regulates proliferation and differentiation of multipotent p63-positive cells isolated from human breastmilk. Cell Cycle 10:278-284.

Wang, L., Y. Lin, Y. Bian, L. Liu, L. Shao, L. Lin, B. Qu, F. Zhao, X. Gao, and Q. Li. 2014. Leucyl-tRNA synthetase regulates lactation and cell proliferation via mTOR signaling in dairy cow mammary epithelial cells. Int. J. Mol. Sci. 15:5952-5969.

Wu, Y., C. Peng, L. Xu, X. Zheng, M. Liao, Y. Yan, Y. Jin, and J. Zhou. 2012. Proteome dynamics in primary target organ of infectious bursal disease virus. Proteomics 12:1844-1859.

Yao, P., and P. L. Fox. 2013. Aminoacyl-tRNA synthetases in medicine and disease. EMBO Mol. Med. 5:332-343.

Zhao, K., H. Y. Liu, M. M. Zhou, and J. X. Liu. 2010. Establishment and characterization of a lactating bovine mammary epithelial cell model for the study of milk synthesis. Cell Biol. Int. 34:717-721. 